Dohara Publisher Open Access Journal

\title{
Original Artikel \\ Pengaruh Pendidikan Kesehatan dengan Audio Visual Terhadap Pengetahuan tentang Covid-19 pada Siswa Kelas 3 SD
}

(The Effect of Health Education with Audio Visual on Knowledge about Covid-19 in Grade 3 Elementary School Students)

\author{
Valeri Lumongga ${ }^{1}$, Hari Ghanesia Istiani ${ }^{2}$, Sancka Stella ${ }^{3}$ \\ SD Tarsisius Vireta Tangerang, Banten, Indonesia \\ Valerilumongga@gmail.com
}

\begin{abstract}
Introduction: Most of the students knowledge of preventing COVID-19 is still a little less good. One of the effort to break the chain of transmission of the COVID-19 virus is by provoding audio-visual health education.

Methods: The research design used Quasi Eksperimental with one-group pre-post test design. The sample taken in this study were 34 respondents who used purposive sampling technique, the instrument used was a questionnaire sheet with a Guttman scale.

Results: This study describes the majority of the distribution on knowledge before being given treatment as many as 18 responden $(52,9 \%)$ lacking knowledge and the frequency distribution of knowledge after being given treatment as many as 18 respondent $(52,9 \%)$ having good knowledge, this study describes the effect of health education with audio visuals on knowledge of COVID-19 in grade $3(\mathrm{p}=0,000)$.
\end{abstract}

Discussion: From the results of the research conducted, it can be concluded that there is an increase in knowledge about COVID-19 after being given audio visual health education.

Keywords: Audio Visuals, COVID-19, Health Education, Knowledge.

\section{Artikel}

Disubmit (Received) : : 14 Oktober 2021

Diterima (Accepted) : 23 Oktober 2021

Diterbitkan (Published) : 29 Oktober 2021

Copyright: (C 2021 by the authors. License DPOAJ, Jakarta, Indonesia. This article is an open access article distributed under the terms and conditions of the Creative Commons

Attribution (CC BY SA) license (https:// creativecommons.org/licenses/by/ 4.0/) 


\section{DPOAJ}

Dohara Publisher Open Access Journal

Volume 01, No.03, Oktober.2021

e-ISSN 2807-310X, p-ISSN 2807-3096

\section{Pendahuluan}

Virus COVID-19 maupun Servere Acute Respiratory Coronavirus 2 (SARS-CoV-2) adalah virus yang bisa melanda sistem pernapasan. ${ }^{1}$ Virus mudah menyebar serta berkembang di paru-paru lewat kontak fisik seperti, hidung, mulut serta mata. ${ }^{2}$ Virus menyebar dengan kilat serta bisa menginfeksi orang tanpa memandang umur. ${ }^{3}$ Ciri dan indikasi orang yang terpapar virus ini merupakan demam diatas $38^{\circ} \mathrm{C}$, batuk, pilek, serta sesak napas.

Berdasarkan hasil survei dari riset, pengetahuan masyarakat yang masih butuh ditingkatkan antara lain tentang pengecekan deteksi dini dengan Rapid Diagnostic Test yang merupakan pengecekan penentu COVID-19. ${ }^{4}$ Pengetahuan warga yang masih kurang akurat hingga masyarakat membutuhkan diedukasi. Secara universal, sebagian besar pengetahuan, sikap serta keahlian warga Provinsi DKI Jakarta menghindari COVID-19 dengan baik, tetapi masih sedikit yang kurang baik. Oleh sebab itu, pemerintah dibantu sektor pendidikan dalam melaksanakan upaya promosi kesehatan dengan langkah-langkah intervensi serta kampanye diperuntukkan untuk pengaruh sikap seseorang. ${ }^{5}$

Kementerian Kesehatan melaporkan terdapat 1.851 kasus COVID-19 pada anak-anak kurang dari 18 tahun dan 29 diantaranya wafat diakibatkan COVID-19.6 Di Banten terdapat 11 kasus anak positif COVID-19, di Kabupaten Tangerang terdapat 24 anak yang terpapar COVID-19 yang berasal dari Kota Tangerang, serta 6 yang terpapar COVID-19 yang berasal dari Kota Tangerang Selatan. ${ }^{7}$ Sedangkan itu, di Kota Tangerang dari jumlah penderita positif COVID-19, meningkat sebanyak 882 kasus, dimana 533 kasus dalam proses perawatan serta 50 kasus dinyatakan meninggal dunia. ${ }^{8}$ Oleh sebab itu, dibutuhkan pengetahuan warga khususnya tentang COVID-19 pada anak, karena untuk memutuskan rantai penularan COVID-19 dibutuhkan uraian serta pengetahuan yang baik dalam seluruh aspek pada anak. Pengetahuan yakni hasil keingintahuan melalui sensoris, paling utama mata serta telinga terhadap objek tertentu. ${ }^{4}$

Pemerintah Republik Indonesia sudah mempraktikkan berbagai macam kebijakan agar pemutusan rantai penularan COVID-19 ini bisa menurun di Indonesia. Kebijakan membatasi kegiatan di luar rumah, kegiatan ibadah di rumah, bekerja dari rumah (work form home), hingga aktivitas belajar mengajar yang seharusnya dilaksanakan di sekolah harus dilaksanakan di rumah. ${ }^{9}$ Aktivitas sekolah yang dirumahkan tersebut bisa terus berjalan dengan memberikan pembelajaran dalam jaringan (online). ${ }^{10}$ Langkah preventif bisa dilakukan dengan metode membagikan penyuluhan tentang virus COVID-19 di Indonesia melalui media-media online yang bisa dijangkau warga. ${ }^{11}$ Penyuluhan dapat dilakukan dengan membagikan pendidikan kesehatan yang bertujuan untuk menaikkan pengetahuan pada anak serta membuat anak lebih paham serta waspada tentang virus COVID-19 dan pencegahannya.

Pendidikan kesehatan ialah kegiatan yang bertujuan untuk mewujudkan perilaku sehat yang berguna bagi kesehatan. ${ }^{12}$ Pendidikan kesehatan pada anak Sekolah Dasar (SD) bisa memberikan dampak yang sangat baik. ${ }^{13}$ Siswa memerlukan media yang bisa menolong untuk belajar secara nyata, salah satunya dengan menggunakan media audio visual. Media audio visual ialah media yang membawakan data atau informasi melalui audio (suara) dan visual (gambar), melalui media ini sangat ideal dalam menyebarkan informasi. ${ }^{14}$ Audio visual memiliki keunggulan yaitu memicu dampak gerak, sehingga nampak lebih menarik perhatian, mudah dipahami oleh anak-anak, serta bisa membuat anak-anak melihat dan mendengar secara bersamaan mengenai materi yang diberikan. ${ }^{15}$ Oleh karena itu, media audio visual sangat efisien untuk digunakan dalam memberikan pendidikan kesehatan kepada anak-anak. Tujuan dalam riset ini untuk mengetahui pengaruh pendidikan kesehatan dengan audio visual terhadap pengetahuan tentang COVID-19 pada siswa kelas 3 di SD Tarsisius Vireta Tangerang Tahun 2020.

\section{Metode}

Desain riset yang digunakan pada riset ini merupakan quasi eksperimen dengan pre dan post tes. Responden pada riset ini merupakan siswa kelas 3 SD. Metode kriteria inklusi serta eksklusi 
digunakan pada riset ini, sehingga jumlah sampel pada penelitian ini sebanyak 34 responden. Variabel yang diteliti adalah pengetahuan tentang COVID-19, untuk melakukan pengukuran dari penelitian menggunakan kuesioner skala Guttman, dimana pemberian pendidikan kesehatan dengan audio visual dilakukan sebanyak satu hari. Analisis informasi pada penelitian ini adalah mencari cerminan pengetahuan sebelum dan setelah diberikan pendidikan kesehatan melalui media audio visual.

Penelitian ini telah sukses lolos uji etik (etical clearance) yang di sahkan oleh komisi etik Sekolah Tinggi Ilmu Kesehatan Indonesia Maju (STIKIM) dengan nomor surat etik 083/Sket/KaDept/RE/STIKIM/I/2021.

\section{Hasil}

Pada hasil analisis data yang digunakan dalam penelitian ini merupakan analisis univariat serta analisis bivariat. Analisis univariat disini hanya menghasilkan distribusi dan presentase dari tiap variabel dan analisis bivariat yang dilakukan terhadap kedua variabel independen dan dependen yang diduga memiliki pengaruh, dengan ini peneliti menggunakan uji statistik yaitu uji Marginal Homogenity yang bertujuan untuk melihat pengaruh pendidikan kesehatan dengan audio visual terhadap pengetahuan tentang COVID-19 pada siswa kelas 3 di SD Tarsisius Vireta Tangerang.

Tabel 1 pengetahuan siswa kelas 3 tentang COVID-19 saat sebelum diberikan pendidikan kesehatan dengan audio visual di SD Tarsisius Vireta Tangerang $(n=34)$

\begin{tabular}{ccc}
\hline Pretest & Frekuensi & $\%$ \\
\hline Baik & 3 & 8,8 \\
\hline Cukup & 13 & 38,2 \\
\hline Kurang & 18 & 52,9 \\
\hline Total & 34 & 100,0 \\
\hline
\end{tabular}

Berdasarkan Tabel 1 di atas, sebanyak 18 responden (52,9\%) dari siswa kelas 3 di SD Tarsisius Vireta Tangerang memiliki pengetahuan kurang sebelum diberikan pendidikan kesehatan melalui audio visual.

Tabel. 2 Pengetahuan siswa kelas 3 tentang COVID-19 setelah diberikan pembelajaran kesehatan dengan audio visual di SD Tarsisius Vireta Tangerang $(n=34)$

\begin{tabular}{ccc}
\hline Postest & Frekuensi & $\%$ \\
\hline Baik & 18 & 52,9 \\
\hline Cukup & 16 & 47,1 \\
\hline Total & 34 & 100,0 \\
\hline
\end{tabular}

Berdasarkan Tabel 2 di atas, sebanyak 18 responden (52,9\%) dari siswa kelas 3 di SD Tarsisius Vireta Tangerang memiliki pengetahuan baik setelah diberikan pendidikan kesehatan melalui audio visual. 
Tabel. 3 Pengaruh pembelajaran kesehatan dengan audio visual terhadap pengetahuan tentang COVID-19 pada siswa kelas 3 di SD Tarsisius Vireta Tangerang Tahun $2020(n=34)$

\begin{tabular}{|c|c|c|c|c|}
\hline Sebelum & Sesudah diberikan Pendkes & & & \\
\hline $\begin{array}{l}\text { diberikan } \\
\text { Pendkes }\end{array}$ & Baik & Cukup & Total & Nilai $\mathbf{P}$ \\
\hline Baik & 2 & 1 & 3 & \\
\hline Cukup & 9 & 4 & 13 & 0,000 \\
\hline Kurang & 7 & 11 & 18 & \\
\hline Total & 18 & 16 & 34 & \\
\hline
\end{tabular}

Berdasarkan hasil Tabel 3 diatas dapat disimpulkan responden dalam penelitian ini berjumlah 34 orang, diketahui nilai signifikansi ataupun Sig. (2-Tailed) Marginal Homogenity sebesar 0,000 lebih kecil dari 0,05 maka ada pengaruh pendidikan kesehatan dengan audio visual terhadap pengetahuan tentang COVID-19 pada siswa kelas 3 di SD Tarsisius Vireta Tangerang.

\section{Pembahasan}

\section{Pengetahuan Siswa Kelas 3 tentang COVID-19 Sebelum diberikan Pendidikan Kesehatan dengan Audio Visual}

Hasil penelitian ini sesuai dengan penelitian yang telah dilakukan oleh Johan, Reni dan Noorbaya (2018) yang berjudul Pengaruh Penyuluhan Media Audio Visual Video Terhadap Perilaku Cuci Tangan Pakai Sabun Pada Siswa Kelas II Di SDN 027 Samarinda. Didapatkan hasil sebelum dilakukan intervensi menampilkan jumlah responden dengan jenis kurang sebanyak 27 responden $(98,2 \%)$ dan kategori baik sebanyak 1 responden $(1,8 \%)$.

Berdasarkan teori yang telah dikemukakan oleh Monintja, bahwa kurangnya pengetahuan serta tingkatan pemahaman yang rendah disinyalir dapat mengakibatkan kurang baiknya kualitas kesehatan masyarakat, kurangnya pengetahuan dengan rendahnya kesadaran akan mengurangi perilaku masyarakat terhadap pemeliharaan kesehatan terutama dalam upaya pencegahan COVID-19 dan terbukti bahwa perilaku yang didasari oleh pengetahuan akan lebih baik dibandingkan perilaku yang tidak didasari oleh pengetahuan dan kesadaran yang baik.

Kurangnya pengetahuan dan pemahaman tentang COVID-19 adalah umum dijumpai setiap negara di dunia. Pengetahuan anak tentang COVID-19 merupakan faktor yang terpenting dalam pemutusan rantai penularan, selain itu kurangnya pengetahuan juga disebabkan oleh kurangnya kemampuan dalam menerima informasi tersebut dikehidupan sehari-hari. Menurut ${ }^{17}$ bahwa pengetahuan ataupun kognitif ialah domain yang sangat berarti dalam membentuk tindakkan seorang.

Salah satu upaya yang digunakan untuk meningkatkan pengetahuan anak adalah dengan memberikan pendidikan kesehatan melalui media audio visual. Sehingga dalam perihal ini peneliti berasumsi bahwa anak usia sekolah dasar yang memiliki pengetahuan minim disebabkan karena kurangnya kesadaran anak terkait pengetahuan kesehatan untuk dirinya sendiri, kurangnya pengetahuan pada seseorang akan memengaruhi kurangnya kemampuan seseorang untuk menerapkan protokol kesehatan dalam kehidupan sehari-hari. Tanpa pengetahuan seseorang tidak mempunyai 
dasar untuk mengambil keputusan dan menentukan tindakan terhadap masalah yang dihadapi. Pengetahuan ialah proses kognitif dari seorang ataupun individu membagikan arti terhadap area, sehingga tiap-tiap individu memberikan makna sendiri terhadap stimulasi yang diterima meski stimulasi itu sama.

\section{Pengetahuan Siswa kelas 3 tentang COVID-19 sesudah diberikan Pendidikan Kesehatan dengan Audio Visual}

Penelitian ini menjelaskan bahwa pengetahuan anak setelah diberikan pendidikan kesehatan dengan audio visual kepada siswa kelas 3 di SD Tarsisius Vireta Tangerang sebanyak 18 responden $(52,9 \%)$ dalam kategori pengetahuan baik.

Hasil penelitian ini sejalan dengan penelitian yang telah dilakukan oleh Roymon (2019) yang berjudul Pengaruh Penyuluhan Identifikasi Pasien dengan Menggunakan Media Audiovisual terhadap Pengetahuan Pasien Rawat Inap dengan memberikan penyuluhan pelaksanaan identifikasi pasien menggunakan media audio visual jumlah pasien dalam kategori pengetahuan mengalami peningkatan, hal ini dapat dilihat sebanyak 12 orang pasien masuk dalam kategori pengetahuan baik, yang sebelumnya tidak ada pasien yang dikategorikan memiliki pengetahuan baik.

Dalam teori yang dikemukakan oleh ${ }^{18}$ penggunaan media terutama media audio visual sangat berpengaruh terhadap keberhasilan peserta didik dalam mencapai tujuan pembelajaran. Hal ini juga dikemukakan oleh ${ }^{19}$ mengatakan manfaat penggunaan media dalam pembelajaran adalah proses pembelajaran menjadi lebih jelas dan menarik, efisiensi waktu dan tenaga, meningkatkan kualitas hasil belajar siswa dan dapat menumbuhkan sikap positif siswa terhadap materi dan proses belajar. Hal ini peranan media audio visual dalam pendidikan kesehatan sangatlah penting dalam proses transformasi ilmu pengetahuan itu sendiri, karena media pembelajaran ini sangat penting untuk memberikan pengalaman serta mempermudah siswa dalam memahami materi yang disampaikan.

Peneliti berasumsi bahwa memberikan pendidikan kesehatan melalui audio visual dapat meningkatkan pengetahuan siswa. Media pembelajaran audio visual ini dapat menarik perhatian siswa sehingga siswa dapat menyimak materi yang diberikan oleh pemateri. Dalam upaya meningkatkan pengetahuan pada siswa kelas 3 di SD Tarsisius Vireta Tangerang, adanya proses pemberian pendidikan kesehatan dengan audio visual tentang COVID-19 dengan penelitian terkait dan pembuktian teori terkait.

\section{Pengaruh Pendidikan Kesehatan dengan Audio Visual terhadap Pengetahuan tentang COVID- 19 pada Siswa Kelas 3}

Penelitian ini menggambarkan adanya pengaruh signifikan antara variabel pendidikan kesehatan dengan audio visual terhadap pengetahuan tentang COVID-19 dengan nilai signifikansi $0,000(\mathrm{p}<0,05)$.

Hasil penelitian ini sejalan dengan penelitian Harsismanto (2019) yang berjudul Pengaruh Pendidikan Kesehatan Media Video dan Poster Terhadap Pengetahuan dan Sikap Anak dalam Pencegahan Penyakit Diare yang berjumlah 15 responden. Didapatkan hasil dengan nilai $\mathrm{P}$ Value = $0,000,0,05$ yang berarti ada pengaruh signifikansi pendidikan kesehatan dengan media poster terhadap sikap anak kelas IV SDN 65 Selumna dalam pencegahan penyakit diare. 


\section{DPOAJ}

Berdasarkan teori dari ${ }^{20}$ Media Audio Visual adalah alternatif yang layak untuk mengoptimalkan proses pembelajaran dari berbagai media. Diantaranya mudah dikemas dalam proses pembelajaran, lebih menarik untuk pembelajaran, dan dapat diedit setiap saat. Audio berkaitan dengan indra pendengaran, pesan yang akan disampaikan akan dituangkan kedalam lambang-lambang auditif, baik verbal maupun non verbal. Visual adalah hal-hal yang berkaitan dengan penglihatan, dihasilkan atau terjadi sebagai gambaran dalam ingatan. Jadi audio visual adalah alat peraga yang bisa ditangkap oleh indra penglihatan dan indra pendengaran yakni yang memiliki unsur suara dan gambar. ${ }^{21} \mathrm{Hal}$ ini dapat digunakan untuk pendidikan kesehatan dalam memberikan materi melalui audio visual, sehingga siswa tidak merasakan kejenuhan dan tertarik dalam mengikuti pendidikan kesehatan ini.

Asumsi peneliti berdasarkan hasil setelah penelitian ini, diketahui bahwa pendidikan kesehatan dapat memengaruhi pengetahuan anak tentang COVID-19. Oleh karena itu, pendidikan kesehatan sangat diperlukan untuk menggugah kesadaran memberikan atau meningkatkan pengetahuan anak tentang pemeliharaan dan peningkatan kesehatan baik bagi dirinya sendiri, keluarga maupun masyarakat. Proses pendidikan kesehatan dalam mencapai tujuan melalui perubahan perilaku anak yang dipengaruhi beberapa faktor, diantaranya materi atau pesan yang disampaikan alat bantu atau alat peraga yang digunakan dalam pendidikan, metode yang digunakan oleh petugas atau pendidik yang melakukan promosi kesehatan. Memberikan pendidikan kesehatan dengan audio visual dapat menarik perhatian anak sehingga dapat meningkatkan pengetahuan anak tentang COVID-19.

Dari hasil analisis univariat dan bivariat dapat ditarik kesimpulannya bahwa sebagian besar pengetahuan pada siswa kelas 3 tentang COVID-19 kurang baik dan adanya pengaruh pendidikan kesehatan dengan Audio Visual terhadap pengetahuan tentang COVID-19 pada siswa kelas 3 di SD Tarsisius Vireta Tangerang Tahun 2020.

\section{References}

1. Nurhalimah N. upaya bela negara melalui sosial distancing dan lockdown untuk mengatasi wabah covid-19 (Efforts to Defend the Country Through Social Distancing and Lockdown to Overcome the COVID-19 plague). SSRN Electron J. 2020;19.

2. Syafrida S. Bersama Melawan Virus Covid 19 di Indonesia. SALAM J Sos dan Budaya Syar-i. 2020;7(6).

3. No V, Mona N. Konsep Isolasi Dalam Jaringan Sosial Untuk Meminimalisasi Efek Contagious (Kasus Penyebaran Virus Corona Di Indonesia). J Sos Hum Terap. 2020;2(2):117-25.

4. Purnamasari I, Raharyani AE. Tingkat Pengetahuan dan Perilaku Masyarakat Kabupaten Wonosobo Tentang Covid-19. J Ilm Kesehat [Internet]. 2020;(Mei):33-42. Available from: https://ojs.unsiq.ac.id/index.php/jik/article/view/1311/783

5. Utami RA, Mose RE, Martini M. Pengetahuan, Sikap dan Keterampilan Masyarakat dalam Pencegahan COVID-19 di DKI Jakarta. J Kesehat Holist. 2020;4(2):68-77.

6. Putri SG. Kematian Anak Indonesia karena Corona Tertinggi di ASEAN, Ini Sebabnya [Internet]. Www.kompas.com. 2020 [cited 2020 Sep 9]. Available from: https://www.kompas.com/sains/read/2020/06/04/170300423/kematian-anak-indonesia-karenacorona-tertinggi-di-asean-ini-sebabnya?Page $=$ all

7. Santoso B. Ya Ampun! 41 Anak di Banten Positif Corona, 284 Berstatus PDP [Internet]. Www.banten.suara.com. 2020 [cited 2020 Sep 9]. Available from: https://banten.suara.com/read/2020/05/31/084450/ya-ampun-41-anak-di-banten-positif-corona284-berstatus-pdp

8. Fauzi IA. Zona Merah, Ini Jumlah Kasus COVID-19 di Kota Tangerang [Internet]. Www.tangerangnews.com. 2020 [cited 2020 Sep 6]. Available from: 


\section{DPO \\ Dohara Publisher Open Access Journal}

Volume 01, No.03, Oktober.2021

e-ISSN 2807-310X, p-ISSN 2807-3096

http://tangerangnews.com/kota-tangerang/read/32616/Zona-Merah-Ini-Jumlah-Kasus-COVID19-di-Kota-Tangerang

9. Yunus NR, Rezki A. Kebijakan Pemberlakuan Lock Down Sebagai Antisipasi Penyebaran Corona Virus Covid-19. SALAM J Sos dan Budaya Syar-i. 2020;7(3).

10. Handarini OI, Wulandari SS. Pembelajaran Daring Sebagai Upaya Study From Home (SFH) Selama Pandemi Covid 19. J Pendidik Adm Perkantoran. 2020;8(3):496-503.

11. Karo MB. Perilaku Hidup Bersih dan Sehat (PHBS) Strategi Pencegahan Penyebaran Virus Covid-19. J Keperawatan Komunitas [Internet]. 2020;01(01):40-7. Available from: W Saputro, LY Budiarti, H Herawati - Dunia Keperawatan, 2016 - ppjp.unlam.ac.id

12. Windasari NN. Pendidikan Kesehatan Dalam Meningkatkan Kepatuhan Merawat Kaki pada Pasien Diabetes Melitus Tipe II. Unpublished. 2014;(1):1-5.

13. Kiki F, Candrawati E, Putri RM. Pengaruh Pendidikan Kesehatan Terhadap Peningkatan Pengetahuan Dalam Pemilihan Jajan Pada Anak Usia Sekolah 7-9 Tahun Desa Ngantru Kecamatan Ngantang Kabupaten Malang. J Nurs News. 2018;XI(1):31-7.

14. Metode I, Pada B, Komunikasi P, Anak E, Spektrum D, Di A, et al. Diajukan kepada Universitas Negeri Surabaya Untuk memenuhi Persyaratan Penyelesaian Program Sarjana Pendidikan Luar Biasa Oleh : achmad fatoni universitas negeri surabaya jurusan pendidikan luar biasa. 2019;1-14.

15. Papilaya EA, Zuliari K, . J. Perbandingan pengaruh promosi kesehatan menggunakan media audio dengan media audio-visual terhadap perilaku kesehatan gigi dan mulut siswa sd. e-gigi. 2016;4(2):1-5.

16. Monintja. Hubungan Antara Karakteristik Individu, Pengetahuan Dan Sikap Dengan Tindakan PSN DBD Masyarakat Kelurahan Malalayang, Kecamatan Malalayang, Kota Manado. Univ. Sam Ratulangi Manad. 2015;5:503-19.

17. Dharmawati IGAA, Wirata IN. Hubungan Tingkat Pendidikan, Umur, Dan Masa Kerja Dengan Tingkat Pengetahuan Kesehatan Gigi Dan Mulut Pada Guru Penjaskes Sd Di Kecamatan Tampak Siring Gianyar. J Kesehat Gigi [Internet]. 2016;4(1):1-5. Available from: http://www.poltekkesdenpasar.ac.id/keperawatangigi/wp-content/uploads/2017/02/ilovepdf_merged.pdf

18. Ananda R. Penggunaan Media Audio Visual untuk Meningkatkan Hasil Belajar Pendidikan Kewarganegaraan Siswa Kelas IV SD Negeri 016 Bangkinang Kota. J Basicedu. 2017;1(1):2130 .

19. Purnomo J. Penggunaan Media Audio-Visual Pada Mata Pelajaran Ilmu Pengetahuan Alam Di Sekolah Menengah Pertama Negeri. J Teknol Pendidik dan Pembelajaran. 2014;2(2):127-44.

20. Rinaldi AA, Daryati D, Arthur R. Penggunaan Media Pembelajaran Berbasis Audio Visual untuk Mata Pelajaran Konstruksi Bangunan. J pensil. 2017;6(1):1-7.

21. Suryaningseh W. Pengaruh Pendidikan Kesehatan Melalui Audiovisual Terhadap Perilaku Bullying Pada Anak Usia Sekolah Di SD Muhammadiyah Mlangi Gamping Sleman Yogyakarta. Univ 'Aisyiyah Yogyakarta [Internet]. 2016; Available from: http://digilib.unisayogya.ac.id/2278/1/naskah publikasi.pdf 